\title{
HUBUNGAN ANTARA PELATIHAN, MOTIVASI DAN KETERSEDIAAN FASILITAS DENGAN PARTISIPASI JUMANTIK DI KOTA BLITAR
}

\author{
Dian Shanti Yunita \\ Departemen Epidemiologi, Fakultas Kesehatan Masyarakat, Universitas Airlangga \\ Surabaya, Jawa Timur, Indonesia \\ Alamat Korespondensi: \\ Dian Shanti Yunita \\ Email: dianshantiy@yahoo.com
}

\begin{abstract}
In Dengue Hemorrhagic Fever (DHF) is a health problem and the number of cases is increasing every year, including in East Java. Blitar City is one of the cities in East Java which is endemic dengue. The Incident Rate (IR) in 2015 which is 70,28 per 100.000 population over the target area that is 21 per 100.000 population. One effort that can be done to reduce the number of dengue cases is increasing activeness jumantik in the prevention of dengue. Jumantik task in the prevention of dengue fever include CHD (Flick Periodic Monitoring), larvasidasi and reporting results of CHD to the clinic regularly. The purpose of this study was to determine and analyze the relationship between training, motivation and availability of facilities with participation jumantik in Blitar City. This study used an analytic observational study with cross sectional study design. Respondents in this study are jumantik in Blitar City with a sample of 171 samples. The data used in this study are primary data and secondary data. Statistical test results obtained value of meaningful relationship training $(p=0,000)$, motivation $(p=0,000)$ and the availability of facilities $(p=0,000)$.Conclusions of this research that thereare a relationship between the training, motivation and availability of facilities with participation jumantik in Blitar City. Suggestions for Blitar City Health Department and clinics in Blitar City which should jumantik training ongoing each year and monitor the results of CHD regularly to anticipate the incidence of DHF.
\end{abstract}

Keywords: Blitar City, Jumantik, Participation

\begin{abstract}
ABSTRAK
Di Indonesia Demam Berdarah Dengue (DBD) masih menjadi masalah kesehatan dan jumlah kasusnya setiap tahun cenderung meningkat, termasuk di Jawa Timur. Kota Blitar adalah salah satu kota di Jawa Timur yang merupakan daerah endemis DBD. Incidence Rate (IR) DBD tahun 2015 yaitu 70,28 per 100.000 penduduk melebihi target daerah yaitu 21 per 100.000 penduduk. Salah satu upaya yang dapat dilakukan untuk menekan jumlah kasus DBD yaitu meningkatkan keaktifan jumantik dalam pencegahan DBD. Tugas jumantik dalam pencegahan DBD meliputi Pemantauan Jentik Berkala (PJB), larvasidasi dan penyuluhan per bangunan sasaran dan pelaporan hasil PJB secara rutin ke puskesmas. Tujuan penelitian ini untuk mengetahui dan menganalisis hubungan antara pelatihan, motivasi dan ketersediaan fasilitas dengan partisipasi jumantik di Kota Blitar. Penelitian observasional analitik dengan desain studi cross sectional melibatkan 171 jumantik Kota Blitar sebagai sampel. Penelitian ini menggunakan data primer dan sekunder. Hasil uji statistik didapatkan nilai hubungan bermakna yaitu pelatihan $(\mathrm{p}=0,000)$, motivasi $(\mathrm{p}=0,000)$ dan ketersediaan fasilitas $(\mathrm{p}=0,000)$. Kesimpulan dari penelitian ini yaitu ada hubungan antara pelatihan, motivasi dan ketersediaan fasilitas dengan partisipasi jumantik di Kota Blitar. Saran untuk Dinkes dan puskesmas Kota Blitar adalah mengadakan pelatihan jumantik berkelanjutan setiap tahun dan memantau hasil PJB secara rutin untuk antisipasi kejadian DBD.
\end{abstract}

Kata kunci: jumantik, partisipasi, Kota Blitar 


\section{PENDAHULUAN}

DBD adalah penyakit yang disebabkan oleh infeksi virus dengue. Penyakit ini ditularkan oleh vektor nyamuk Aedes aegypti dan Aedes albopictus yang mempunyai kebiasaan menggigit mangsanya pada saat siang hari. Masa inkubasi virus ini adalah 2 sampai 10 hari di dalam tubuh vektor dan akan muncul di kelenjar liur nyamuk dan siap menginfeksi manusia yang tergigit (Soegijanto, 2004).

Virus dengue terdapat dalam darah penderita 1-2 hari sebelum demam. Virus tersebut berada dalam darah (viremia) penderita selama masa periode intrinsik 3-14 hari (ratrata 4-7 hari). Pada suhu $30^{\circ} \mathrm{C}$ di dalam tubuh nyamuk Aedes aegypti memerlukan waktu 8-10 hari untuk menyelesaikan masa inkubasi ekstrinsi dari lambung sampai ke kelenjar ludah nyamuk (Depkes RI, 2002).

DBD merupakan salah satu penyakit menular yang sering muncul dan berkembang di daerah tropis. Indonesia merupakan salah satu negara tropis yang menjadi negara endemis DBD. Kementerian Kesehatan Republik Indonesia mencatat insiden DBD per 100.000 penduduk mulai tahun 1968 hingga saat ini menunjukkan kecenderungan peningkatan (Kemenkes RI, 2010).

Diagnosis gejala DBD dibedakan menjadi kriteria klinis dan laboratories. Kriteria klinis terdiri dari demam tinggi mendadak tanpa sebab jelas berlangsung selama 2-7 hari, terdapat manifestasi perdarahan, pembesaran hati dan syok yang ditandai dengan nadi kecil dan cepat, hipotensi, kaki dan tangan dingin, kulit lembab dan pasien tampak gelisah. Kriteria laboratories ditandai dengan trombositopeni $\left(100.000 / \mathrm{mm}^{3}\right.$ atau kurang) dan hemakonsentrasi dapat dilihat dari peningkatan hematokrit $20 \%$ atau lebih menurut standar umum dan jenis kelamin (Soegijanto, 2004).

Penularan penyakit DBD melalui gigitan nyamuk Aedes. Nyamuk Aedes terdiri dari beberapa spesies diantaranya Ae.aegypti, Ae. albopictus dan Ae. scutellaris yang dapat menjadi vektor. Nyamuk Aedes dapat menularkan virus dengue pada manusia secara langsung (menggigit orang dalam fase viremia) maupun secara tidak langsung setelah melewati masa inkubasi dalam tubuhnya selama 8-10 hari. Manusia infektif hanya pada saat viremia saja (5-7 hari) tetapi nyamuk dapat infektif selama hidupnya (Soewandojo, 2002).

Penularan DBD dapat terjadi di semua tempat yang terdapat nyamuk penular DBD. Tempat potensial penularan DBD diantaranya wilayah endemis DBD, tempat-tempat umum yang merupakan tempat berkumpulnya orang-orang datang dari berbagai wilayah sehingga memungkinkan adanya pertukaran beberapa tipe virus dengue (sekolah, sarana kesehatan, hotel, pertokoan, pasar, restoran, tempat ibadah) dan pemukiman baru pinggir kota dengan penduduk yang umumnya berasal dari berbagai wilayah (Depkes RI, 2005).

Bionomik vektor nyamuk ada 5, meliputi kesenangan tempat perindukan nyamuk, kesenangan nyamuk menggigit, kesenangan nyamuk istirahat, lama hidup dan jarak terbang banyak. Pertama, kesenangan tempat perindukan nyamuk biasanya berupa genangan air yang tertampung di suatu tempat atau bejana. Nyamuk Aedes tidak dapat berkembang biak digenangan air yang langsung bersentuhan dengan tanah. Genangan yang disukai sebagai tempat perindukan nyamuk Aedes berupa genangan air yang tertampung di suatu wadah yang biasanya disebut kontainer atau tempat penampungan air bukan genangan air di tanah. Nyamuk Aedes lebih tertarik meletakkan telurnya pada TPA (Tempat Penampungan Air) berair yang berwarna gelap, terbuka lebar dan terutama yang terletak di tempat-tempat terlindung matahari. Tempat perindukan Aedes yaitu tempat dimana nyamuk ini meletakkan telurnya baik di dalam rumah maupun di luar rumah.

Tempat perindukan yang ada di dalam rumah paling utama adalah tempat-tempat 
penampungan air seperti baik mandi, bak air WC maupun tendon. Kedua yaitu kesenangan nyamuk menggigit biasanya pada pagi hari dan sore hari. Nyamuk Aedes aegypti betina sangat menyukai darah manusia. Nyamuk betina ini mempunyai kebiasaan menghisap darah berpindahpindah berkali-kali dari satu individu ke individu lainnya. Ketiga yaitu kesenangan nyamuk istirahat, kebiasaan istirahat nyamuk Aedes banyak di dalam rumah pada bendabenda yang bergantung, berwarna gelap dan di tempat-tempat lain yang terlindung. Tempat-tempat tersebut, nyamuk menunggu proses pematangan telur. Setelah istirahat dan proses pematangan telur selesai, nyamuk betina akan meletakkan telurnya di dinding tempat perkembangbiakannya, sedikit diatas permukaan air. Pada umumnya telur akan menetas menjadi jentik dalam waktu kurang lebih 2 hari setelah telur terendam air. Keempat yaitu jarak terbang nyamuk ini terbatas sampai jarak $100 \mathrm{~m}$ dari lokasi kemunculan. Penyebaran nyamuk Aedes aegypti dipengaruhi oleh beberapa faktor termasuk ketersediaan tempat bertelur dan darah. Transportasi pasif dapat berlangsung melalui telur dan larva yang ada di dalam penampung. Kelima adalah lama hidup di mana nyamuk Aedes dewasa memiliki ratarata lama hidup kurang lebih 8 hari. Selama musim hujan, saat masa bertahan hidup lebih panjang, risiko penyebaran virus semakin besar (Soegijanto, 2006).

Stratifikasi endemisitas daerah potensial DBD dibagi menjadi 4 daerah yaitu pertama daerah endemis adalah daerah yang dalam 3 tahun terakhir setiap tahunnya ditemukan kasus DBD. Kedua daerah sporadis yaitu daerah yang dalam 3 tahun terakhir ditemukan kasus tetapi tidak setiap tahun berturut-turut. Ketiga yaitu daerah potensial adalah daerah yang dalam 3 tahun terakhir tidak pernah ditemukan kasus DBD tetapi memiliki potensi besar dengan melihat persentase rumah yang memiliki jentik $>5 \%$ perumahan padat penduduk dan mempunyai hubungan transportasi yang ramai dengan wilayah lain sehingga memiliki risiko terjadi KLB (Kejadian Luar Biasa). Keempat daerah bebas yaitu daerah yang dalam 3 tahun terakhir tidak pernah ditemukan kasus dan memiliki potensial kecil untuk terjadinya penularan dengan melihat potensi persentase rumah yang memiliki jentik $<5 \%$ (Kemenkes RI, 2015).

Ada beberapa cara pemberantasan DBD antara lain dengan cara pemberantasan nyamuk dewasa dan pemberantasan jentik. Pemberantasan nyamuk dewasa dapat dilakukan dengan cara penyemprotan (fogging) dengan insektisida. Pemberantasan jentik dapat dilakukan dengan tiga cara yaitu cara fisik dikenal sebagai kegiatan $3 \mathrm{M}$ (menguras dan menyikat bak mandi, menutup tempat penampung air dan mengubur barang-barang bekas penampung air. Cara kedua yaitu kimia dengan menggunakan larvasida temephos. Cara yang ketiga yaitu biologi menggunakan ikan pemakan jentik atau Bacillus thuringiensis var Israeliensis (Depkes RI, 2005).

Jawa Timur selama 3 tahun menduduki peringkat tiga besar untuk jumlah kasus DBD terbanyak di Indonesia. Dinkes Kota Blitar menyebutkan bahwa jumlah kasus DBD di Kota Blitar cenderung meningkat selama 5 tahun terakhir (2011-2015) dengan jumlah kasus berturut-turut yaitu 9 kasus, 44 kasus, 77 kasus, 87 kasus dan 97 kasus. Jumlah kasus DBD akan cenderung meningkat dari tahun ke tahun.

IR di Kota Blitar juga cenderung mengalami peningkatan dari tahun 20132015 dengan IR berturut-turut yaitu 56,72 per 100.000 penduduk, 63,5 per 100.000 penduduk dan 70,28 per 100.000 penduduk. Angka tersebut melebihi target daerah yaitu 21 per 100.000 penduduk. Hal ini menunjukkan bahwa DBD masih menjadi permasalahan kesehatan di Kota Blitar yang harus segera diselesaikan (Dinkes Kota Blitar, 2016).

Peran jumantik sangat penting dalam sistem kewaspadaan dini mewabahnya DBD karena berfungsi untuk melakukan 
PJB. Jumantik adalah kader yang berasal dari masyarakat di suatu daerah, yang pembentukan dan pengawasan kinerja bertanggungjawab sepenuhnya oleh pemerintah kabupaten/kota (Kemenkes RI, 2012). Jumantik bertugas memantau jentik nyamuk dari rumah ke rumah. Peran serta langsung masyarakat adalah kegiatan PJB oleh kader jumantik. PJB adalah pemantauan dan pemeriksaan tempattempat perkembangbiakan nyamuk Aedes aegypti yang dilakukan secara teratur oleh jumantik (Depkes RI, 2005). Pada pelaksanaan Pemberantasan Sarang Nyamuk (PSN) jumantik dibekali PSN kit berupa topi, rompi, tas kerja, alat tulis, senter, pipet dan plastic tempat jentik dan larvasida (Kemenkes RI, 2015). Berdasarkan data sekunder dari Dinkes Kota Blitar, keaktifan jumantik mengalami penurunan yaitu tahun 2014 hanya 210 orang jumantik yang aktif dan menjadi 105 orang jumantik aktif di tahun 2015 dari 416 orang toal jumantik di Kota Blitar.

Partisipasi masyarakat adalah ikut sertanya seluruh anggota masyarakat dalam memecahkan permasalahan-permasalahan masyarakat tersebut. Partisipasi dibidang kesehatan yaitu keikutsertaan seluruh anggota masyarakat dalam memecahkan masalah kesehatan mereka sendiri dan masyarakat aktif memikirkan, memecahkan melaksanakan dan mengevaluasi programprogram kesehatan. Dalam partisipasi setiap anggota masyarakat dituntut suatu kontribusi atau sumbangan. Sumbangan tersebut bukan hanya terbatas pada dana dan financial saja tetapi dapat berbentuk tenaga, uang, bendabenda dan ide atau gagasan (Notoatmodjo, 2007).

Tujuan penelitian ini adalah menganalisis hubungan antara pelatihan, motivasi dan ketersediaan fasilitas dengan partisipasi jumantik di Kota Blitar. Ada 4 faktor yang mempengaruhi partisipasi masyarakat dalam pemberantasan penyakit antara lain adalah pendidikan, penghasilan, pekerjaan dan ketersediaan fasilitas menunjukkan angka yang signifikan terhadap pengaruh partisipasi masyarakat (Dalimunthe, 2008). Pelatihan dan pendidikan diperlukan untuk mengerahkan kecapakan, kemampuan, keterampilan dan potensi seseorang (Hasibuan, 2003).

Motivasi kerja karyawan dipengaruhi oleh kebutuhan fisik, kebutuhan keamanan dan keselamatan, kebutuhan sosial, kebutuhan penghargaan diri dan kebutuhan aktualisasi diri. Faktor kebutuhan tersebut diturunkan menjadi 5 indikator untuk mengetahui motivasi kerja karyawan. Pertama fisologis atau kebutuhan fisik yang ditunjukkan dengan pemberian gaji yang layak kepada pegawai, pemberian bonus, uang makan, uang transportasi, fasilitas perumahan. Kedua keamanan, ditunjukkan dengan fasilitas keamanan dan keselamatan kerja diantaranya seperti adanya jaminan sosial tenaga kerja, dana pensiun, tunjangan kesehatan, asuransi kesehatan dan perlengkapan keselamatan kerja. Ketiga kebutuhan sosial ditunjukkan dengan melakukan interaksi dengan orang lain yang diantaranya dengan menjalin hubungan kerja yang harmonis, kebutuhan untuk diterima dalam kelompok dan kebutuhan untuk mencintai dan dicintai. Keempat yaitu penghargaan ditunjukkan dengan pengakuan dan penghargaan berdasarkan kemampuan yaitu kebutuhan untuk dihormati dan dihargai oleh karyawan lain dan pimpinan terhadap prestasi kerjanya. Kelima yaitu aktualisasi diri ditunjukkan dengan sifat pekerjaan yang menarik dan menantang dimana karyawan akan mengerahkan kecakapan, kemampuan, keterampilan dan potensinya. Dalam pemenuhan kebutuhan ini dapat dilakukan dengan menyelenggarakan pendidikan dan pelatihan (Hasibuan, 2003). Teori Motivasi Kesehatan, motivasi dipengaruhi faktorfaktor seperti kebijakan, administrasi perusahaan dan gaji yang memadai dalam suatu pekerjaan (Hasibuan, 2003).

Berdasarkan penelitian Yamin (2003) menyebutkan bahwa ketersediaan fasilitas mempengaruhi partisipasi seseorang dalam 
melaksanakan tugasnya. Fasilitas yang diperlukan jumantik dalam pelaksanaan tugasnya sesuai dengan Petunjuk Teknis Pemberantasan Sarang Nyamuk DBD oleh Jumantik adalah formulir hasil pemeriksaan jentik, PSN kit (topi, rompi, tas kerja, alat tulis, senter, pipet dan plastik tempat jentik dan larvasida) serta media KIE seperti leaflet DBD (Kemenkes RI, 2015). Di Kota Blitar jumantik dibekali senter dan larvasida dalam melaksanakan PJB. Peran aktif jumantik diharapkan dapat menurunkan angka kesakitan dan kematian akibat DBD sehingga mampu meningkatkan derajat kesehatan masyarakat.

\section{METODE PENELITIAN}

Penelitian ini menggunakan desain studi observasional dengan rancang bangun cross sectional. Lokasi penelitian di 3 kecamatan di Kota Blitar yaitu Kecamatan Sananwetan, Sukorejo dan Kepanjen kidul pada April sampai Mei 2016. Populasi penelitian adalah seluruh jumantik yang berjumlah 416 bertugas lebih dari 1 tahun yang tercatat di wilayah kerja puskesmas di Kota Blitar. Penghitungan besar sampel menggunakan rumus cross sectional didapatkan hasil 171 sampel, yang dibagi dalam 3 kecamatan di Kota Blitar dengan menggunakan metode proportional random sampling. Variabel terikat dari penelitian ini adalah partisipasi jumantik di Kota Blitar dalam melaksanakan PJB, larvasida dan penyuluhan per bangunan sasaran serta pelaporan hasil PJB. Variabel bebas dalam penelitian ini adalah pelatihan jumantik, motivasi jumantik dan ketersediaan fasilitas bagi jumantik. Pelatihan jumantik merupakan pernah atau tidaknya responden mendapatkan pelatihan jumantik selama satu tahun terakhir. Motivasi jumantik merupakan alasan responden bersedia menjadi jumantik. Ketersediaan fasilitas merupakan ketersediaan fasilitas pendukung pemantauan jentik dan pencegahan DBD (PSN kit : senter, larvasida, rompi/topi, kartu jentik, form lapangan). Pengolahan dan analisis data menggunakan 4 tahapan. Pertama yaitu editing memeriksa kembali kelengkapan jawaban responden. Kedua yaitu scoring adalah memberi nilai pada jawaban untuk selanjutnya dikategorikan dan diberi kode. Ketiga yaitu entry adalah memasukkan data ke computer. Keempat yaitu analisis menggunakan uji statistik Chi Square untuk melihat hubungan antara variabel terikat dengan variabel bebas.

\section{HASIL \\ Gambaran Umum Kota Blitar}

Kota Blitar terdiri dari 3 kecamatan yang masing-masing terbagi dalam 7 kelurahan. Kota Blitar berbatasan langsung dengan wilayah Kabupaten Blitar karena posisinya berada di tengah-tengah Kabupaten Blitar. Sebelah utara berbatasan dengan Kecamatan Nglegok dan Garum. Sebelah selatan berbatasan dengan Kecamatan Sanankulon dan Kanigoro. Sebelah Barat berbatasan dengan Kecamatan Sanankulon dan Nglegok. Sebelah Timur berbatasan dengan Kecamatan Kanigoro dan Garum. Luas wilayah Kota Blitar adalah kurang lebih $32.578 \mathrm{~km}^{2}$ dengan 21 kelurahan serta memiliki 3 puskesmas yang terletak di masing-masing kecamatan. Tahun 2015 total penduduk Kota Blitar sebanyak 144.838 jiwa dengan rincian jumlah penduduk laki-laki sebanyak 72.161 jiwa dan jumlah penduduk perempuan sebanyak 72.677 jiwa. Kepadatan penduduk di Kota Blitar dari tahun 2011 sampai 2015 berturut-turut adalah 4,$36 ; 4,13 ; 4,17 ; 4,2$ dan 4,24. Ketinggian rata-rata Kota Blitar dari permukaan laut adalah $156 \mathrm{~m}$ dan termasuk dataran rendah. Bagian utara Kota Blitar relatif lebih tinggi dibandingkan dengan wilayah bagian selatan. Ketinggian bagian utara sekitar $245 \mathrm{~m}$ dari permukaan air laut dengan kemiringan $2^{\circ}$ sampai $15^{\circ}$. Ketinggian wilayah semakin ke selatan semakin menurun yaitu bagian tengah sekitar $175 \mathrm{~m}$ dan bagian selatan 140 $\mathrm{m}$ dengan tingkat kemiringan $0^{\circ}$ sampai $2^{\circ}$. Iklim di Kota Blitar ditandai dengan adanya pergantian musim setiap tahun. Kota Blitar yang terletak di sekitar garis khatulistiwa 
sebagaimana wilayah lain di Provinsi Jawa Timur dan wilayah lain di Indonesia yang dipengaruhi oleh dua musim setiap tahunnya yaitu musim hujan dan musim kemarau. Iklim di Kota Blitar meliputi keadaan curah hujan dan intensitas hujan. Kondisi iklim ditandai dengan adanya bulan basah dan bulan kering. Kota Blitar memiliki tipe iklim C. Posisi Kota Blitar tidak jauh dari Gunung Kelud dengan ketinggian $156 \mathrm{~m}$ diatas permukaan laut sehingga cukup berpengaruh terhadap curah hujan dan hari hujan.

Jumlah jumantik di Kota Blitar pada masing-masing kecamatan adalah 60 (Kecamatan Sananwetan), 106 (Kecamatan Sukorejo) dan 250 (Kecamatan Kepanjen kidul). Dari 21 kelurahan, 14 diantaranya merupakan daerah endemis DBD. Daerah tersebut adalah Sananwetan, Bendogerit, Karangtengah, Plosokerep, Klampok, Rembang, Sukorejo, Pakunden, Karangsari, Tanjungsari, Kepanjen kidul, Kepanjenlor, Sentul dan Kauman. Nilai ABJ di Kota Blitar cenderung sama pada tahun 2011 sampai 2015 dengan rincian berurutan $86 \%, 77 \%, 88 \%, 90 \%$ dan $83 \%$ namun IR DBD cenderung meningkat dengan rincian berurutan $6 \%$, 32\%, 57\%, 63\% dan $70 \%$.

\section{Karakretistik Responden}

Seluruh responden dalam penelitian ini adalah perempuan dengan golongan usia produktif sebanyak $98,2 \%$ dan sebanyak $1,8 \%$ berusia tidak produktif. Tingkat pendidikan sebagian besar responden yaitu pendidikan menengah (tamat SLTA) sebanyak $86,0 \%$, lainnya sebanyak $7,6 \%$ pendidikan tinggi (tamat PT) dan 6,4\% pendidikan dasar (SD, tamat SD, tamat SLTP). Mayoritas responden bekerja sebagai ibu rumah tangga atau tidak bekerja sebanyak $78,4 \%$ dan sisanya bekerja sebagai wiiraswasta atau swasta. Sebanyak 55,6\% responden melaksanakan pelatihan dengan baik (minimal 1 kali dalam satu tahun) dan sebanyak $66,7 \%$ responden melakukan pelatihan kurang (tidak pernah). Responden yang memiliki motivasi baik sebanyak $71,9 \%$ sedangkan responden dengan motivasi kurang sebanyak 28,1\%. Responden yang menerima ketersediaan fasilitas baik sebanyak $63,7 \%$ dan untuk responden yang menerima ketersediaan fasilitas kurang sebanyak 36,3\%.

\section{Hubungan Antara Pelatihan Jumantik dengan Partisipasi Jumantik di Kota Blitar}

Jumantik yang mengikuti pelatihan jumantik dengan baik sebanyak 58 orang $(61,1 \%)$ aktif dalam partisipasi jumantik sedangkan jumantik dengan pelatihan yang kurang sebanyak 24 orang $(31,6 \%)$ aktif dalam partisipasi jumantik seperti terlihat pada tabel 1 .

Tabel 1. Hubungan Antara Pelatihan dengan Partisipasi Jumantik di Kota Blitar

\begin{tabular}{|c|c|c|c|c|c|c|}
\hline \multirow{3}{*}{ Kriteria } & \multicolumn{4}{|c|}{ Partisipasi Jumantik } & \multirow{2}{*}{\multicolumn{2}{|c|}{ Total }} \\
\hline & \multicolumn{2}{|c|}{ Aktif } & \multicolumn{2}{|c|}{$\begin{array}{c}\text { Kurang } \\
\text { Aktif }\end{array}$} & & \\
\hline & $\mathbf{N}$ & $\%$ & $\mathbf{N}$ & $\%$ & $\mathbf{N}$ & $\%$ \\
\hline Baik & 58 & 61,1 & 37 & 38,9 & 95 & 100 \\
\hline Kurang & 24 & 31,6 & 52 & 68,4 & 75 & 100 \\
\hline Total & 82 & 48,0 & w89 & 52,0 & 171 & 100 \\
\hline
\end{tabular}

Hasil uji statistik Chi-Square didapatkan nilai $\mathrm{p}=0,000(\alpha=0,05)$, hal ini berarti ada hubungan yang bermakna antara pelatihan jumantik dengan partisipasi jumantik di Kota Blitar dengan nilai PR $($ Prevalence Ratio $)=1,933(95 \%$ CI PR $=$ $1,338-2,793)$.

\section{Hubungan Antara Motivasi dengan Partisipasi Jumantik di Kota Blitar}

Jumantik dengan motivasi baik sebanyak 76 orang $(61,8 \%)$ aktif dalam partisipasi jumantik sedangkan jumantik dengan motivasi kurang sebanyak 6 orang $(12,5 \%)$ aktif dalam partisipasi jumantik seperti terlihat pada tabel 2 . 
Tabel 2. Hubungan Antara Motivasi dengan Partisipasi Jumantik di Kota Blitar

\begin{tabular}{llccccc}
\hline \multirow{2}{*}{ Kriteria } & \multicolumn{4}{c}{ Partisipasi Jumantik } & \multirow{2}{*}{ Aktif } & \multicolumn{2}{c}{$\begin{array}{c}\text { Kurang } \\
\text { Aktif }\end{array}$} & & \\
\cline { 2 - 6 } & \multicolumn{4}{c}{ Total } \\
\cline { 2 - 6 } & $\mathbf{N}$ & $\mathbf{\%}$ & $\mathbf{N}$ & $\mathbf{\%}$ & $\mathbf{N}$ & $\mathbf{\%}$ \\
\hline Baik & 76 & 61,8 & 47 & 38,2 & 123 & 100 \\
Kurang & 6 & 12,5 & 42 & 87,5 & 48 & 100 \\
\hline Total & 82 & 48,0 & 89 & 52,0 & 171 & 100 \\
\hline
\end{tabular}

Uji statistik Chi-Square didapatkan nilai $\mathrm{p}=0,000(\alpha=0,05)$, hal ini berarti bahwa ada hubungan bermakna antara motivasi dengan partisipasi jumantik di Kota Blitar dengan nilai PR $=4,943(95 \%$ CI PR $=2,309-10,583$ ).

\section{Hubungan Antara Ketersediaan Fasilitas dengan Partisipasi Jumantik di Kota Blitar}

Jumantik yang mendapatkan fasilitas baik sebanyak 68 orang $(63,3 \%)$ aktif dalam partisipasi jumantik sedangkan jumantik yang mendapatkan fasilitas kurang sebanyak 13 orang $(21,0 \%)$ aktif dalam partisipasi jumantik seperti terlihat pada tabel 3 .

Uji statistik Chi-Square didapatkan nilai $\mathrm{p}=0,000(\alpha=0,05)$, hal ini berarti ada hubungan yang bermakna antara ketersediaan fasilitas dengan partisipasi jumantik di Kota Blitar dengan nilai PR $=3,019(95 \%$ CI PR $=1,824-4,997)$.

Tabel 3. Hubungan Antara Ketersediaan Fasilitas dengan Partisipasi Jumantik di Kota Blitar

\begin{tabular}{lcccccc}
\hline \multirow{3}{*}{ Kriteria } & \multicolumn{2}{c}{ Partisipasi Jumantik } & \multirow{2}{*}{ Total } \\
\cline { 2 - 6 } & Aktif & \multicolumn{3}{c}{$\begin{array}{c}\text { Kurang } \\
\text { Aktif }\end{array}$} & & \\
\cline { 2 - 6 } & $\mathbf{N}$ & $\mathbf{\%}$ & $\mathbf{N}$ & $\mathbf{\%}$ & $\mathbf{N}$ & $\mathbf{\%}$ \\
\hline Baik & 69 & 63,3 & 40 & 36,7 & 109 & 100 \\
Kurang & 13 & 21,0 & 49 & 79,0 & 62 & 100 \\
\hline Total & 82 & 48,0 & 89 & 52,0 & 171 & 100 \\
\hline
\end{tabular}

\section{PEMBAHASAN}

\section{Kejadian DBD di Kota Blitar}

Jumlah kasus DBD di Kota Blitar tergolong tinggi dan cenderung muncul setiap tahunnya di Kota Blitar sehingga pada tahun 2015 dinyatakan daerah endemis DBD. Sebagian besar kelurahan di Kota Blitar merupakan daerah endemis DBD. Peningkatan jumlah kasus DBD dari waktu ke waktu disebabkan karena pendidikan, pekerjaan, semakin tinggi mobilisasi penduduk, keberadaan tempat penampungan air, keberadaan tanaman hias dan pekarangan serta jarak antar rumah (Roose, 2008). Penelitian Wati (2009) menyebutkan bahwa peningkatan kejadian DBD disebabkan oleh keberadaan jentik Aedes pada kontainer, kebiasaan menggantung pakaian, ketersediaan tutup pada kontainer, frekuensi pengurasan pada kontainer dan pengetahuan masyarakat tentang DBD.

Kota Blitar memiliki mobilitas dan kepadatan penduduk yang tinggi akibat perpindahan penduduk dari luar kota ke dalam kota ataupun sebaliknya dan juga disebabkan oleh angka kematian dan jumlah kelahiran di wilayah tersebut. Kota Blitar termasuk dalam kategori padat penduduk. Kepadatan penduduk merupakan potensial penularan cepat penyakit DBD.

Nyamuk Aedes dapat berkembang dengan baik di daerah dataran rendah akibat suhu dan kelembaban pada dataran rendah cocok untuk perkembangan nyamuk tersebut. Kota Blitar masuk ke dalam daerah dataran rendah di mana daerah ini disukai oleh nyamuk Aedes.

\section{Partisipasi Jumantik di Kota Blitar}

Jumantik adalah kader posyandu yang telah ditunjuk dan diminta oleh pihak pusksmas. Sebanyak 48\% jumantik di Kota Blitar aktif berpartisipasi melaksanakan tugasnya. Tugas jumantik adalah melakukan pemeriksaan jentik nyamuk penular demam berdarah dengue termasuk memotivasi keluarga atau masyarakat dalam melaksanakan PSN DBD (Depkes RI, 2005). 
Mayoritas jumantik melakukan PJB selama 3 bulan sekali serta pelaporan hasil PJB paling banyak dilakukan 3 bulan sekali sebanyak $42,7 \%$. Hal ini tidak sesuai dengan peran jumantik dalam menanggulangi DBD yaitu mencatat dan melaporkan hasil PJB kepada Kepala Dusun atau puskesmas secara rutin setiap minggu dan bulanan (Depkes RI, 2005).

Peran jumantik lainnya adalah melakukan PSN dan pemberantasan DBD secara sederhana seperti pemberian bubuk larvasida dan ikan pemakan jentik (Depkes RI, 2005). Pada pelaksanaan larvasida dan penyuluhan per bangunan sasaran, sebagian jumantik tidak membawa larvasida yaitu sebanyak 39,8\%. Berdasarkan pengumpulan data primer, sebagian besar jumantik membagikan larvasida hanya bila ada kasus DBD di daerah tersebut. Alasan lain jumantik tidak membawa larvasida yaitu ada penolakan dari warga untuk tidak diberi larvasida karena mereka menganggap larvasida mencemari sumber air. Peran jumantik di sini adalah memotivasi dan meningkatkan pengetahuan warga yang kurang memahami cara pencegahan dan pemberantasan DBD dengan baik dan benar.

\section{Faktor yang Berhubungan dengan Partisipasi Jumantik}

Berdasarkan hasil analisis uji ChiSquare diperoleh variabel yang berhubungan dengan partisipasi jumantik. Ketiga variabel yang diteliti yaitu pelatihan, motivasi dan ketersediaan fasilitas memiliki hubungan signifikan dengan partisipasi jumantik. Jumantik dengan pelatihan baik memiliki kecenderungan aktif dalam partisipasi jumantik sebesar 1,933 kali lebih besar daripada jumantik dengan pelatihan kurang baik. Semakin banyak pelatihan jumantik yang diikuti oleh jumantik maka semakin tinggi pula partisipasinya untuk aktif dalam melaksanakan tugasnya. Pelatihan dan pendidikan diperlukan untuk mengerahkan kecakapan, kemampuan, keterampilan dan potensi seseorang (Hasibuan, 2003). Sesuai dengan hasil penelitian Ningrum et al. (2013) menyatakan bahwa pendidikan dan pelatihan dapat meningkatkan kemampuan karyawan untuk melaksanakan tugasnya sesuai ketentuan yang berlaku. Penelitian yang dilakukan oleh Kumara et al. (2016) juga menyebutkan bahwa pelatihan dapat meningkatkan kepemimpinan sehingga dapat mempengaruhi kerja seseorang. Pelatihan jumantik dibutuhkan untuk meningkatkan tingkat pengetahuan jumantik terkait DBD serta untuk meningkatkan keterampilan dan kecakapan jumantik dalam melaksanakan tugasnya. Dalam pelaksanaan pelatihan jumantik, jumantik dilatih cara melakukan pemeriksaan jentik dengan benar dan dibekali peralatan senter. Hasil pemeriksaan yang ditunjukkan oleh ada tidaknya jentik di suatu rumah dicatat pada form pemantauan jentik yang disediakan oleh puskesmas.

Motivasi memiliki hubungan signifikan dengan partisipasi jumantik. Motivasi adalah proses mempengaruhi atau mendorong dari luar terhadap seseorang atau kelompok kerja agar mereka mau melaksanakan sesuatu yang telah ditetapkan (Syamsudin, 2005). Jumantik yang memiliki motivasi baik cenderung aktif 4,943 kali lebih besar daripada jumantik yang memiliki motivasi kurang. Pada hasil penelitian Murti et al. (2013) menyebutkan bahwa motivasi memiliki hubungan signifikan dengan kerja pegawai. Penelitian Sutrischastini et al. (2015) juga menyatakan bahwa ada hubungan signifikan antara motivasi dengan kinerja seseorang. Motivasi kerja karyawan dipengaruhi oleh kebutuhan fisik, kebutuhan akan keamanan dan keselamatan, kebutuhan sosial, kebutuhan akan penghargaan diri dan kebutuhan aktualisasi diri (Hasibuan, 2003). Semakin baik motivasi jumantik maka akan semakin baik pula jumantik dalam melaksanakan tugasnya. Salah satu faktor yang mempengaruhi motivasi adalah imbalan. Hal ini sesuai dengan Teori Motivasi Kesehatan yang dikemukakan oleh Herzberg yaitu faktor-faktor seperti kebijakan, administrasi perusahaan dan gaji 
yang memadai dalam suatu pekerjaan akan menentramkan karyawan. Menurut Herzberg apabila faktor-faktor tersebut terpenuhi maka motivasi karyawan akan baik serta kinerja juga baik (Hasibuan, 1990).

Ketersediaan fasilitas memiliki hubungan signifikan dengan partisipasi jumantik. Jumantik yang menerima ketersediaan fasilitas baik memiliki kecenderungan aktif sebesar 3,019 kali lebih besar daripada jumantik yang menerima ketersediaan fasilitas kurang. Hasil penelitian ini sesuai dengan hasil penelitian yang dilakukan oleh Hartono (2014) yang menyatakan bahwa ketersediaan fasilitas berhubungan dengan kinerja seseorang karena pelaksanaan tugas karyawan dapat berjalan maksimal apabila fasilitas yang didapatkan memadai. Potu (2013) dalam penelitiannya juga menyatakan lingkungan kerja termasuk ketersediaan fasilitas memiliki hubungan signifikan dengan kinerja pegawai. Menurut teori perilaku Green, faktor pendukung munculnya perilaku seseorang adalah tersedianya fasilitas atau sarana pendukung. Jumantik dalam menjalankan tugasnya membutuhkan fasilitas kesehatan untuk mendorong pelaksanaan tugasnya tersebut (Notoatmodjo, 2007). Pada Petunjuk Teknis Pemberantasan Sarang Nyamuk DBD oleh Jumantik disebutkan bahwa fasilitas yang diperlukan untuk pelaksanaan partisipasi jumantik diantaranya topi, rompi, tas kerja, alat tulis, senter, pipet dan plastik tempat jentik dan larvasida (Kemenkes RI, 2015).

\section{SIMPULAN}

Berdasarkan hasil penelitian dan pembahasan yang telah diuraikan pada bab sebelumnya, maka dapat disimpulkan bahwa ada hubungan antara pelatihan jumantik dengan partisipasi jumantik di Kota Blitar. Ada hubungan antara motivasi dengan partisipasi jumantik di Kota Blitar. Ada hubungan antara ketersediaan fasilitas dengan partisipasi jumantik di Kota Blitar. Saran untuk Dinas Kesehatan dan Puskesmas yaitu hendaknya melaksanakan pelatihan jumantik berkelanjutan setiap tahunnya untuk meningkatkan pengetahuan jumantik terkait cara penularan dan pencegahan DBD serta memantau secara rutin hasil PJB yang dilakukan jumantik sebagi upaya antisipasi kasus DBD.

\section{DAFTAR PUSTAKA}

Dalimunthe. 2008. Faktor-faktor yang Mempengaruhi Partisipasi Masyarakat Dalam Program Pencegahan Malaria di Kecamatan Saibu Kabupaten Mandailing Natal. Tesis.Fakultas Kesehatan Masyarakat Universitas Indonesia.

Departemen Kesehatan Republik Indonesia.1999. Rencana Pembangunan Kesehatan Menuju Indonesia Sehat 2010. Depkes RI.

Departemen Kesehatan Republik Indonesia .2002.Pedoman Survei Entomologi Demam Berdarah Dengue. Depkes RI.

Departemen Kesehatan Republik Indonesia. 2005. Pencegahan dan Pemberantasan Demam Berdarah Dengue di Indonesia. Depkes RI.

Dinas Kesehatan Kota Blitar.2016. Profil Kesehatan Kota Blitar 2015.Blitar : Dinas Kesehatan Kota Blitar.

Hartono, D. 2014. Pengaruh Sarana Prasarana dan Lingkungan Kerja Terhadap Kinerja Pegawai Dinas Pendidikan Kota Banjarbaru. (Online). Vol. 10, No. 2, Tersedia di < http://sia. stiepancasetia.ac.id/download-jurnal. php?id=103> Diakses 25 Juli 2016

Hasibuan. 1990. Organisasi dan Motivasi. Jakarta : PT Raja Grafindo Parsada.

Hasibuan. 2003. Organisasi dan Motivasi. Jakarta : PT Raja Grafindo Parsada.

Kementrian Kesehatan Republik Indonesia. 2010. Demam Berdarah Dengue. Buletin Jendela Epidemiologi (Online), 1 : 2. Tersedia di $:<$ http://www.depkes. go.id/downloads/publikasi/buletin/ BULETIN\%20DBD.pdf)>Diakses 18 Juli 2016. 
Kementrian Kesehatan Republik Indonesia.2012. Petunjuk Teknis Pemberantasan Sarang Nyamuk Demam Berdarah (PSNDBD) oleh Juru Pemantau Jentik (Jumantik). Jakarta. Kemenkes RI

Kementrian Kesehatan Republik Indonesia. 2015. Petunjuk Teknis Pemberantasan Sarang Nyamuk Demam Berdarah Dengue (PSN DBD) oleh Juru Pemantau Jentik (Jumantik). Jakarta. Kemenkes RI

Kumara, ESWI., Utama, MWI. 2016. Pengaruh Pelatihan Terhadap Kinerja Karyawan dengan Mediasi Kepemimpinan Pada Hotel Satriya Cottages Kuta-Bali. (Online). Vol. 5, No. 3, Tersedia di $<$ http://download.portalgaruda.org/ article.php? article $=411637 \& \mathrm{val}=989 \& \mathrm{ti}$ tle $=$ PENGARUH $\% 20$ PELATIHAN $\% 20$ TER HAD A P $\% 20$ K IN ER J A $\% 20$ KARYAWA N\%20DENGAN\%20 MEDIASI $\% 20$ KEPEMIMPINAN $\% 20$ PADA $\% 20 H O T E L \% 20$ SATRIYA $\%$ 20COTTAGES\%20KUTA\%20BALI> Diakses 25 Juli 2016

Murti, Harry., Srimulyani, AV. 2013. Pengaruh Motivasi Terhadap Kinerja Pegawai dengan Variabel Pemediasi Kepuasan Kerja Pada PDAM Kota Madiun. (Online). Vol. 1, No. 1., Tersedia di <https://www.google.co.id/url?sa=t $\& \mathrm{rct}=\mathrm{j} \& \mathrm{q}=\&$ esrc $=\mathrm{s} \&$ source $=$ web \&cd $=2 \& \mathrm{cad}=$ rja\&uact $=8 \& \mathrm{ved}=0$ ahUKEwi s9emD5o3OAhVFrI8KHWOrDeIQFg gqMAE\&url=http $\% 3 \mathrm{~A} \% 2 \mathrm{~F} \% 2 \mathrm{Fportal}$. widyamandala.ac.id $\% 2$ Fjurnal $\% 2$ Findex. php $\% 2$ Fjrma $\% 2$ Farticle $\% 2$ Fdownload $\%$ 2F $82 \% 2 F 85 \&$ usg=AFQjCNHYYQtIkM 9mJB8HWCAmExsguh7bZQ\&bvm=bv. 127984354,d.c2I> Diakses 25 Juli 2016

Ningrum,W., Sunuharyo, SB., Hakam, SM. 2013. Pengaruh Pendidikan dan Pelatihan Terhadap Kinerja Karyawan. (Online), Vol. 6 , No. 2, Tersedia di < http://administrasibisnis.studentjournal. ub.ac.id/index.php/jab/article/view/303> Diakses 25 Juli 2016
Notoatmodjo, S. 2007. Promosi Kesehatan dan Ilmu Perilaku. Jakarta : Rineka Cipta.

Potu, A. 2013. Kepemimpinan, Motivasi dan Lingkungan Kerja Pengaruhnya Terhadap Kinerja Karyawan Pada Kanwil Ditjen Kekayaan Negara Suluttenggo dan Maluku Utara di Manado. (Online). Vol. 1, No. 4, Tersedia di $<$ https://www.google.co.id/l? $\mathrm{sa}=\mathrm{t} \& \mathrm{rct}=\mathrm{j} \& \mathrm{q}=\&$ esrc $=\mathrm{s} \&$ source $=$ web $\& \mathrm{c}$ $\mathrm{d}=10 \& \mathrm{cad}=\mathrm{rja} \&$ uact $=8 \& \mathrm{ved}=0$ ahUKEw iMxoaq743OAhUGM48KHdDlCn0QFg hqMAk\&url=http $\% 3 \mathrm{~A} \% 2 \mathrm{~F} \% 2 \mathrm{Fejournal}$. unsrat.ac.id $\% 2$ Findex.php $\% 2 \mathrm{Femba} \% 2 \mathrm{~F}$ article $\% 2$ Fdownload\%2F2894\%2F 2445 \&usg=AFQjCNHCKUHsDIXhSiNwid2 5-EKf9RfGLw\&bvm=bv.127984354,d. c2I> Diakses 25 Juli 2016

Roose.2008. Hubungan Sosiodemografi dan Lingkungan dengaan Kejadian Penyakit Demam Berdarah Dengue (DBD) di Kecamatan Bukit Raya Kota Pekanbaru. Tesis. Universitas Sumatera Utara.

Soegijanto.2004. Kumpulan Makalah Penyakit Tropis dan Infeksi di Indonesia. Surabaya: University Press.

Soegijanto. 2006. Demam Berdarah Dengue. Edisi ke-2.Surabaya : Airlangga University Press.

Soewandojo, 2002. Seri Penyakit Tropik Infeksi Perkembangan Terkini Dalam Pengelolaan Beberapa Penyakit Tropik Infeksi. Surabaya: University Press.

Sutrischastini, A., Riyanto, A. 2015. Pengaruh Motivasi Kerja Terhadap Kinerja Pegawai Kantor Sekretariat Daerah Kabupaten Gunungkidul. (Online) Vol. 23, No. 2, Tersedia di < http://webcache. googleusercontent.com/search? $\mathrm{q}=\mathrm{cac}$ he:iVhOch8qjn4J:stieww.ac.id/jurnal/ index.php/kb/article/download/48/47+\& $\mathrm{cd}=1 \& \mathrm{hl}=\mathrm{en} \& \mathrm{ct}=\mathrm{clnk} \& \mathrm{gl}=\mathrm{id}>$ Diakses 25 Juli 2016

Syamsudin, A. 2005.Psikologi Kependidikan. Bandung : Rosda.

Wati, EW. 2009. Beberapa Faktor yang Berhubungan dengan Kejadian Demam Berdarah (DBD) di Kelurahan Pacitan 
50 The Indonesian Journal of Public Health, Vol. 11 No. 1, Desember 2016: 40-50

Tahun 2009.Skripsi.Universitas Muhammadiyah Surakarta.Tersedia di $:<$ http://etd.eprints.ums.ac.id/5966/1/ J410050022.PDF> Diakses 7 Juni 2016. Yamin, Ahmad. 2003. Analisis Perbedaan Faktor Yang Berkontribusi Terhadap Pemanfaatan Posyandu oleh Pengunjung Rutin dan Tidak Rutin dalam Konteks Keperawatan Komunitas di Wilayah Kecamatan Limus Nunggal, Boros dan Cikundul Kota Sukabumi Tahun 2002.
Tesis.Program Studi Ilmu Keperawatan Pasca Sarjana UI. Tersedia di: http:// perpus.fkik.uinjkt.ac.id/file_digital/ NITA\%20KURNIA.pdf [9 Juni 2016] Yunita, SD. 2016. Hubungan Antara Karakteristik, Dukungan Keluarga dan Ketersediaan Fasilitas dengan Partisipasi Jumantik di Kota Blitar. Skripsi.Program Sarjana Program Studi Kesehatan Masyarakat Universitas Airlangga Surabaya. 